\title{
Expression, purification and functional characterization of recombinant human acyl-CoA-binding protein (ACBP) from erythroid cells
}

\author{
Katarzyna Augoff ${ }^{\bowtie}$, Adam Kolondra², Anna Chorzalska², Agnieszka Lach², Krzysztof \\ Grabowski ${ }^{1}$ and Aleksander F. Sikorski2 ${ }^{\circledR}$ \\ 1Department of Gastrointestinal and General Surgery, Wroclaw Medical University, 2Laboratory of Cytobiochemistry, Biotechnology Faculty, \\ University of Wroclaw, Wroclaw, Poland
}

Fatty acyl-CoA esters are extremely important in cellular homeostasis. They are intermediates in both lipid metabolism and post-translational protein modifications. Among these modification events, protein palmitoylation seems to be unique by its reversibility which allows dynamic regulation of the protein hydrophobicity. The recent discovery of an enzyme family that catalyze protein palmitoylation has increased the understanding of the enzymology of the covalent attachment of fatty acids to proteins. Despite that, the molecular mechanism of supplying acyl-CoA esters to this reaction is yet to be established. Acyl-coenzyme A-binding proteins are known to bind long-chain acyl-CoA esters with very high affinity. Therefore, they play a significant role in intracellular acyl-CoA transport and pool formation. The purpose of this work is to explore the potential of one of the acyl-CoA-binding proteins to participate in the protein palmitoylation. In this study, a recombinant form of ACBP derived from human erythroid cells was expressed in $E$. coli, purified, and functionally characterized. We demonstrate that recombinant hACBP effectively binds palmitoyl-CoA in vitro, undergoing a shift from a monomeric to a dimeric state, and that this ligand-binding ability is involved in erythrocytic membrane phosphatidylcholine (PC) remodeling but not in protein acylation.

Keywords: acyl-CoA-binding protein, ACBP, DBI, phosphatidylcholine, PC

Received: 19 April, 2010; revised: 06 October, 2010; accepted:

13 November, 2010; available on-line: 16 November, 2010

\section{INTRODUCTION}

Long-chain acyl-CoA esters are not only intermediates of lipid biosynthesis but also potent regulators of enzymes, ion channels and various signal-transducing effectors (Færgeman et al., 1997). They activate ATP-sensitive $\mathrm{K}^{+}\left(\mathrm{K}_{\text {ATP }}\right)$ channels, modulate intracellular $\mathrm{Ca}^{2+}$, activate atypical protein kinase $\mathrm{C}(\mathrm{PKC})$ isoforms, directly stimulate insulin secretion (Shrago, 2000; Hu et al., 2005), act as inhibitors of the nuclear thyroid hormone receptor, and promote the fusion of transport vesicles with the Golgi apparatus during secretory processes (Pfanner et al., 1990). Many specific functions attributed to longchain acyl-CoA esters are due to their involvement in lipid modification of proteins. These modifications significantly increase the protein's hydrophobicity, which can affect both protein-lipid and protein-protein interactions resulting in the proper localization and assembly of modified peptides, and ensuring the stability and activity of the protein complexes (Linder \& Deschenes, 2007). In fact, decreased intracellular availability of acyl-CoA esters in cells strongly affects membrane structure and organization in vivo, and triggers cascades of reactions leading to serious cellular defects and clinical diseases (Mitchell et al., 2008).

On the other hand, the amphipathic character of the long-chain acyl-CoAs makes them one of the most powerful disrupters of the membrane bilayer (Boylan \& Hamilton, 1992). Free long-chain acyl-CoA esters may also have a damaging effect on certain enzymes, resulting in their non-specific inhibition. Therefore, the storage, transport and availability of fatty acid CoA derivatives are of critical importance in cellular homeostasis. In this context, acyl-CoA-binding proteins (ACBPs) seem to play a crucial role. It is strongly suggested that ACBPs are the most significant intracellular acyl-CoA pool formers and regulators of the cytosolic and membraneanchored free acyl-CoA concentration (Færgeman et al., 2007).

ACBPs are small, highly conserved proteins found as several isoforms in a wide range of species, from lower eukaryotic organisms such as yeast, to mammals. Although neither the physiological function nor the mechanism of their action are fully understood, it is known that all of them typically bind saturated and unsaturated C14-C22 fatty acyl-CoA esters with a high affinity $\left(K_{\mathrm{d}}\right.$, values from $4.5 \times 10^{-14}$ to $\left.4.0 \times 10^{-7} \mathrm{M}\right)$ (Gossett et al., 1996; Færgeman et al., 2007) but are unable to bind free fatty acids, acyl-carnitines or cholesterol (Rosendal et al., 1993). Binding long-chain acyl-CoA esters to ACBPs renders them incapable of damaging membranes and protects them from uncontrolled hydrolysis by thioesterases (Jolly et al., 2000). On the other hand, it has been observed that acylCoA esters liganded to ACBPs are favoured over free acyl-CoAs by certain enzymes that utilize activated forms of fatty acids in lipid metabolism (Rasmussen et al., 1994; Fyrst et al., 1995). It is also very likely that enzymes involved in the lipid modification of proteins

Katarzyna Augoff e-mail: augoffka@chir.am.wroc.pl; Aleksander F. Sikorski e-mail: afsbc@ibmb.uni.wroc.pl

Accession number: Homo sapiens diazepam-binding inhibitor (DBI; GABA receptor modulator, or acyl-Coenzyme-A-binding protein), transcript variant 1 (NCBI Reference Sequence: NM 020548.5)

Abbreviations: DMSO, dimethylsulfoxide; DSS, disuccinimidyl suberate; DTT, dithiothreitol; PAT, protein acyltransferase; PC, phosphatidylcholine; PE, phosphatidylethanolamine; PMSF, phenylmethylsulfonyl fluoride 
may prefer acyl-CoAs complexed with a protein carrier. However, this has not been demonstrated yet. As have been shown human red blood cells contain a 10$\mathrm{kDa}$ protein cross-reacting with an antibody directed against a liver-specific ACBP isoform, and protein acyltransferase (PAT) is present in human erythrocyte membranes (Fyrst et al., 1995; Schmidt et al., 1995), we aimed, using an erythrocyte model, to investigate whether this ACBP is involved in the formation of the cellular palmitoyl-CoA pool, whether it donates palmitoyl-CoA for endogenous lipid palmitoylation, and above all, whether it is able to participate in protein palmitoylation as a supplier of the lipid substrate to PAT.

In this study, we report on the characterization of a recombinant human ACBP isoform designated ACBP/ $\mathrm{DBI} / \mathrm{EZ}$, which is derived from erythroid cells. To determine if this ACBP binds palmitoyl-CoA (pal-CoA), desorbs membrane-bound pal-CoA and supplies it for transacyltion, we expressed it as a (His) ${ }_{6}$-tagged recombinant protein containing full-length native human amino-acid sequence, formed and purified its functional complex with $\left[{ }^{14} \mathrm{C}\right]$ palmitoyl-CoA (pal-CoA), and used it for the palmitoylation of membrane phospholipids and recombinant human membrane palmitoylated protein (MPP-1; p55). We used freshly prepared erythrocyte membranes as a source of PAT.

\section{MATERIALS AND METHODS}

Construction of (His) ${ }_{6}$-hACBP/pRSET A and (His)_-GFP-MPP-1/pRSET A plasmids. Total reticulocytic RNA isolation was performed with the RNeasy kit (Qiagen, USA). RT-PCR amplifications were performed with the One-Step RT-PCR kit (Qiagen, Hilden, Germany). Primers used for full-length cDNA synthesis and amplification of human $A C B P / D B I / E Z$ (342 bp) were as follows: forward 5'-gatggggatccgaccgagctatgtggggcgac-3'; BamHI site underlined and reverse 5'-cagatctcg aggtaa ccaaatc cagtctc tcttatc/gataagagagactggatttggttacctcgagatctg-3'; XhoI site underlined. Each RT-PCR $(25 \mu \mathrm{l})$ was performed beginning with denaturation at $94^{\circ} \mathrm{C}$ for $15 \mathrm{~min}$, followed by 30 cycles of $94^{\circ} \mathrm{C}$ for $30 \mathrm{~s}, 60^{\circ} \mathrm{C}$ for $30 \mathrm{~s}$, and $72^{\circ} \mathrm{C}$ for $30 \mathrm{~s}$, with a final 4 min extension at $72^{\circ} \mathrm{C}$. The PCR products were electrophoresed in a $1 \%$ agarose gel.

Plasmid with the human MPP1/p55 cDNA sequence was supplied by Harvard Institute of Proteomics (HIP). Primers used for amplification of MPP-1/ p55 (1398 bp) were as follows: forward 5'-cgacctcgagatgaccctcaaggcgagcgag-3'; XhoI site underlined and reverse 5'-gatcaagcttacttgtacagctcgtccatgc/gcatggacgagctgtacaagtaagcttgatc-3'; HindIII site underlined. Each PCR reaction $(50 \mu \mathrm{l})$ was performed beginning with denaturation at $94^{\circ} \mathrm{C}$ for $5 \mathrm{~min}$, followed by $30 \mathrm{cy}$ cles of $94^{\circ} \mathrm{C}$ for $30 \mathrm{~s}, 58^{\circ} \mathrm{C}$ for $30 \mathrm{~s}$, and $72^{\circ} \mathrm{C}$ for 2 min, with a final 10 min extension at $72^{\circ} \mathrm{C}$. The PCR products were electrophoresed in a $1 \%$ agarose gel. The (His) ${ }_{6}$-GFP-MPP1/p55 construct consists of 776 amino-acid residues, including 287 of the (His) ${ }_{6}$-GFP sequence on the $\mathrm{N}$-terminus of the MPP1 protein and an additional, 23 residue tag on the C-terminus of the protein to improve its stability.

Purified PCR fragments were ligated into the vectors (Invitrogen, Carlsbad, USA) by incubating the insert and vector at $42^{\circ} \mathrm{C}$ for $45 \mathrm{~s}$. The ligation mixtures were used to transform Escherichia coli XL1-Blue
(Stratagene, La Jolla, USA). Clones with the (His) ${ }_{6}-$ hACBP/pRSET A or (His) GFP-MPP1/pRSET A plasmids were selected via colony PCR with T7-pET and T7-termi primers. Plasmids from the positive colonies were isolated, and their sequences were further confirmed by DNA sequencing. To obtain high yield of the rhACBP and rhMPP-1 proteins, BL21 bacteria were transformed with the (His) ${ }_{6}$-hACBP/pRSET A or (His) ${ }_{6}$ GFP-MPP1/pRSET A plasmids. The molecular masses of rhACBP and rhMPP-1 were 21.14 $\mathrm{kDa}$ and $88.62 \mathrm{kDa}$, respectively, as calculated with the ExPASy-ProtParam tool.

Expression of rhACBP and the acceptor protein rhMPP1/p55 in $\boldsymbol{E}$. coli. To yield a laboratory preparative scale recombinant protein expression, starter cultures of $8 \mathrm{ml}$ of Luria-Bertani (LB) medium containing ampicillin $(50 \mu \mathrm{g} / \mathrm{ml})$ and chloramphenicol $(34 \mu \mathrm{g} / \mathrm{ml})$ were inoculated with a single bacterial colony each and then incubated at $37^{\circ} \mathrm{C}$ for about $8 \mathrm{~h}$ to $\mathrm{OD}_{600}=0.6-1.0$. Bacterial pellets were resuspended in $1 \mathrm{ml}$ of LB medium and transferred to $200 \mathrm{ml}$ of fresh LB medium with ampicillin and chloramphenicol. The cultures were incubated at $37^{\circ} \mathrm{C}$ with shaking $(225 \mathrm{rpm})$ until the $\mathrm{OD}_{600}$ reached $\cong 1$. Isopropyl $\beta$-thiogalactopyranoside (IPTG) was added to the culture to a final concentration of 1 $\mathrm{mM}$, and the incubation was continued for another $2 \mathrm{~h}$. Then the bacteria were chilled on ice and centrifuged at $5000 \times g$ for $5 \mathrm{~min}$. The bacterial pellets were collected and frozen at $-80^{\circ} \mathrm{C}$.

Purification of the rhACBP and rhMPP-1/p55 proteins. The bacterial cells were thawed on ice and then resuspended in 5 vol. of lysis buffer ( $20 \mathrm{mM}$ Tris/ $\mathrm{HCl}, 8 \mathrm{M}$ urea, $\mathrm{pH}$ 7.0). They were next incubated on ice for $15 \mathrm{~min}$ to allow thorough lysis. The resulting lysate was passed through an injection needle $(0.8 \mathrm{~mm})$ three times, and centrifuged at $35000 \times g$ for $20 \mathrm{~min}$. The supernatant was loaded on a TALONTM Metal Affinity Resin (Clontech, Mountain View, USA) column $(1 \mathrm{~cm} \times 5 \mathrm{~cm})$ equilibrated with lysis buffer. The column was washed with a buffer $(20 \mathrm{mM}$ Tris/ $\mathrm{HCl}, 8$ $\mathrm{M}$ urea, $1 \mathrm{mM}$ imidazole, $\mathrm{pH} 7.0$ ), and the His-tagged proteins were eluted with eluting buffer $(20 \mathrm{mM}$ Tris/ $\mathrm{HCl}, 150 \mathrm{mM}$ imidazole, $8 \mathrm{M}$ urea, $\mathrm{pH}$ 7.0). Fractions of $1 \mathrm{ml}$ were collected and the absorbance at $280 \mathrm{~nm}$ was estimated. The respective absorbance coefficients for rhACBP and rhMPP-1 were calculated of 2.26 and 0.874 absorbance units. Results of the recombinant protein expression and purification were verified by sodium dodecyl sulfate/polyacrylamide gel electrophoresis (SDS/PAGE). The proteins were dialysed against phosphate-buffered saline $\left(8.1 \mathrm{mM} \mathrm{Na} \mathrm{HPO}_{4}, 2.1 \mathrm{mM}\right.$ $\mathrm{KH}_{2} \mathrm{PO}_{4}, 2.7 \mathrm{mM} \mathrm{KCl}, 137 \mathrm{mM} \mathrm{NaCl}, \mathrm{pH}$ 7.4, containing $0.2 \mathrm{mM}$ PMSF) at $4^{\circ} \mathrm{C}$ for $12 \mathrm{~h}$.

Binding of rhACBP with palmitoyl-CoA. The ability of rhACBP to bind palmitoyl-CoA was determined in a radioactive-labelled palmitoyl-CoA binding assay. The binding was performed in the presence of $1 \mu \mathrm{M}$ rhACBP and increasing concentrations $(0.0625$ to $2 \mu \mathrm{M})$ of $\left[{ }^{14} \mathrm{C}\right]$ pal-CoA (specific radioactivity $40-60 \mathrm{mCi} / \mathrm{mmol}$; Hartmann Analytic, Braunschweig, Germany) in $100 \mu \mathrm{l}$ of incubation buffer $\left(8.1 \mathrm{mM} \mathrm{Na}{ }_{2} \mathrm{HPO}_{4}, 2.1 \mathrm{mM} \mathrm{KH} \mathrm{PO}_{4}\right.$, $2.7 \mathrm{mM} \mathrm{KCl}, 137 \mathrm{mM} \mathrm{NaCl}, 1 \mathrm{mM}$ EGTA, $1 \mathrm{mM} \mathrm{MgCl}$, $1 \mu \mathrm{M} \mathrm{ZnSO}, 1 \mathrm{mM}$ DTT, $0.2 \mathrm{mM}$ PMSF, pH 7.4). The mixture was incubated at $37^{\circ} \mathrm{C}$ for $30 \mathrm{~min}$, and then the recombinant protein was adsorbed on the TALON resin for $1 \mathrm{~h}$ at $4{ }^{\circ} \mathrm{C}$ with shaking. Supernatant was discarded and the resin was washed with $500 \mu \mathrm{l}$ of incubating buffer. The bound protein was eluted with $100 \mu$ l of eluting 
buffer $(20 \mathrm{mM}$ Tris/HCl, $200 \mathrm{mM}$ imidazole, $\mathrm{pH}$ 7.0). To determine the equilibrium dissociation constant $\left(K_{\mathrm{d}}\right)$, $2 \mu \mathrm{l}$ of each sample solution was dotted onto nitrocellulose, dried and subjected to fluorography. The integrated density of the scanned spots was analysed using ImageJ software. The amount of the ligand bound to the protein was calculated on the basis of pixel density, from the dependence of density on known $\left[{ }^{14} \mathrm{C}\right] \mathrm{pal}-\mathrm{CoA}$ concentrations.

The binding of pal-CoA to recombinant ACBP was visualised by continuous native polyacrylamide gel electrophoresis. Samples $(30 \mu \mathrm{l})$ were mixed $3: 2(\mathrm{v} / \mathrm{v})$ with $10 \%$ glycerol, loaded on a pre-run $12 \%$ gel, and electrophoresed. After drying, Coomassie blue-stained gel was exposed on a phosphor screen for $24 \mathrm{~h}$ and scanned on a TYPHOON 8600 Phosphor Imager (Molecular Dynamics, Sunnyvale, CA, USA).

DSS crosslinking. A membrane-permeable, bifunctional amine-reactive crosslinking agent, disuccinimidyl suberate (DSS), was used to examine the level of rhACBP oligomerisation in its apo and liganded form. Purified human recombinant ACBP was diluted to the concentration of $200 \mu \mathrm{g} / \mathrm{ml}$ in PBS (pH 7.4) and incubated at $37^{\circ} \mathrm{C}$ for $30 \mathrm{~min}$ in the presence or absence of $1.5 \mathrm{mM}$ pal-CoA. Then DSS dissolved in DMSO was added to the incubating mixture $(0.025 \mathrm{mM}$ final $)$ and incubated at room temperature for $30 \mathrm{~min}$. The crosslinking reaction was stopped by adding 10 volumes of chlorophorm/methanol solution $(1: 1, \mathrm{v} / \mathrm{v})$. The precipitated protein after centrifugation for $15 \mathrm{~min}$ at $15000 \times \mathrm{g}$ was resuspended in $30 \mu \mathrm{l}$ of Laemmli $2 \times$ buffer, reduced for $5 \mathrm{~min}$ at $95^{\circ} \mathrm{C}$, and analysed by SDS/PAGE in a $14 \%$ gel.

Non-enzymatic palmitoylatio of rhMPP-1/p55 in the presence of $\mathrm{rhACBP} / \mathrm{pal}-\mathrm{CoA}$ complex. The rhACBP/pal-CoA complex was prepared by pre-incubation of a mixture of rhACBP with $\left[{ }^{14} \mathrm{C}\right] \mathrm{pal}-\mathrm{CoA}$ in a $1: 1$ molar ratio for $30 \mathrm{~min}$ at $37^{\circ} \mathrm{C}$ and subsequent purification by affinity chromatography on TALON resin (1 $\mathrm{h} / 4^{\circ} \mathrm{C}$ ) to achieve a $100-\mu \mathrm{M}$ concentration of the protein. To test the availability of the palmitate complexed with ACBP for protein palmitoylation, $15 \mu \mathrm{g}$ of the acceptor protein (rhMPP-1/p55) was incubated in a total volume of $100 \mu \mathrm{l}$ of incubation buffer $\left(8.1 \mathrm{mM} \mathrm{Na} \mathrm{m}_{2} \mathrm{H}\right.$ $\mathrm{PO}_{4}, 2.1 \mathrm{mM} \mathrm{KH} \mathrm{PO}_{4}, 2.7 \mathrm{mM} \mathrm{KCl}, 137 \mathrm{mM} \mathrm{NaCl}, 1$ $\mathrm{mM}$ EGTA, $1 \mathrm{mM} \mathrm{MgCl}, 1 \mu \mathrm{m} \mathrm{ZnSO}_{4}, 1 \mathrm{mM}$ DT'T, $0.2 \mathrm{mM}$ PMSF, $\mathrm{pH} 7.4)$ with $\left[{ }^{14} \mathrm{C}\right] \mathrm{pal}-\mathrm{CoA}$ bound to $10 \mu \mathrm{M}$ rhACBP or $2.5 \mu \mathrm{M}$ free $\left[{ }^{14} \mathrm{C}\right] \mathrm{pal}-\mathrm{CoA}$ as a control. The incubation $\left(3 \mathrm{~h} / 37^{\circ} \mathrm{C}\right)$ was stopped by adding $1 \mathrm{ml}$ of chloroform/methanol solution $(1: 1, \mathrm{v} / \mathrm{v})$. The precipitated protein after centrifugation for $15 \mathrm{~min}$ at $15000 \times g$ was resuspended in $25 \mu \mathrm{l}$ of SDS/PAGE sample buffer ( $8 \%$ SDS, $7.0 \%$ glycerol, $40 \mathrm{mM} \mathrm{DTT}$, $0.25 \mathrm{M}$ Tris/HC1, $0.008 \%$ bromophenol blue, $\mathrm{pH} 6.8)$, reduced for $5 \mathrm{~min}$ at $95^{\circ} \mathrm{C}$, and analysed by SDS/PAGE in a $12 \%$ gel. After staining and drying, the gel was exposed to CL-XPosure Film (Pierce, Rockford, USA) for 4 weeks at $-80^{\circ} \mathrm{C}$.

Red blood cell membrane preparation. Fresh human venous blood obtained from healthy donors was collected into EDTA tubes (Sarstedt, Nümbrecht, Germany). Leukocytes and platelets were removed after centrifugation at $800 \times g$ for $10 \mathrm{~min}$. Red blood cells were washed $3 \times$ in a 5 -fold volume of isoosmotic phosphate buffer, pH 7.4 (Dodge et al., 1963), containing $5 \mathrm{mM}$ glucose. Five volumes of $20 \mathrm{mosM}$ buffer was used to lyse the erythrocytes. The haemolysate was centrifuged for $15 \mathrm{~min}$ at $14000 \times \mathrm{g}$. Mem- branes were collected and washed at least three times with the same buffer to obtain pale and opalescent ghosts, and finally suspended in 1 volume of incubating buffer (8.1 mM Na $\mathrm{HPO}_{4}, 2.1 \mathrm{mM} \mathrm{KH} \mathrm{PO}_{4}, 2.7$ $\mathrm{mM} \mathrm{KCl}, 137 \mathrm{mM} \mathrm{NaCl}, 1 \mathrm{mM}$ EGTA, $1 \mathrm{mM} \mathrm{MgCl}$, $1 \mu \mathrm{M} \mathrm{ZnSO}, 1 \mathrm{mM}$ DTT, $0.2 \mathrm{mM}$ PMSF, pH 7.4) and packed for $20 \mathrm{~min}$ at $20000 \times \mathrm{g}$.

Extraction of pal-CoA from cell membranes by rhACBP. To measure the extraction of membranebound pal-CoA by rhACBP, radiolabelled pal-CoA in concentration of $5 \mu \mathrm{M}$ was first incubated for $30 \mathrm{~min}$ at room temp. with $35 \mu \mathrm{l}$ of fresh-packed ghosts to which $100 \mu \mathrm{l}$ of incubation buffer $\left(8.1 \mathrm{mM} \mathrm{Na} \mathrm{HPO}_{4}, 2.1 \mathrm{mM}\right.$ $\mathrm{KH}_{2} \mathrm{PO}_{4}, 2.7 \mathrm{mM} \mathrm{KCl}, 137 \mathrm{mM} \mathrm{NaCl}, 1 \mathrm{mM}$ EGTA, 1 $\mathrm{mM} \mathrm{MgCl}_{2}, 1 \mu \mathrm{M} \mathrm{ZnSO}_{4}, 1 \mathrm{mM}$ DTT, $0.2 \mathrm{mM}$ PMSF, $\mathrm{pH} 7.4$ ) was added. The samples were washed $3 \times$ with $500 \mu \mathrm{l}$ of incubation buffer to remove non-anchored pal-CoA. Then rhACBP was added to the membrane suspension to $10 \mu \mathrm{M}$ and incubated in a total volume of $100 \mu \mathrm{l}$ for $1 \mathrm{~h}$ at $37^{\circ} \mathrm{C}$. As a control an equal volume of buffer was added to the membrane suspension instead of the recombinant protein. Supernatants were analysed by continuous native gel electrophoresis. Membrane pellets were washed with incubating buffer and suspended in $400 \mu \mathrm{l}$ of chloroform/methanol solution $(2: 1, \mathrm{v} / \mathrm{v})$ to extract membrane-bound pal-CoA. The extracts $(45 \mu \mathrm{l})$ underwent thin-layer chromatography (TLC) on silica plates (Polygram ${ }^{\circledR}$ Sil G, Macherey Nagel Co, Germany) and were separated with a freshly prepared solvent system of 1-propanol/pyridine/acetic acid/water (45:30:9:36, by vol.). The chromatogram was developed until the solvent front reached $0.5 \mathrm{~cm}$ from the top of the plate in tanks lined with solventsaturated filter paper. After drying, the plates were analysed by fluorography for $24 \mathrm{~h}$.

Incubation of $\mathrm{rhACBP} / \mathrm{pal}-\mathrm{CoA}$ complex with erythrocyte ghosts. To test the transfer of palmitate from pal-CoA bound to the carrier protein to membrane phospholipids, $10 \mu \mathrm{M}$ holo-rhACBP (prepared as described above) or free pal-CoA $(2.5 \mu \mathrm{M})$ was added to $35 \mu$ l of a packed native or heat-inactivated $\left(20 \mathrm{~min}\right.$ at $\left.56^{\circ} \mathrm{C}\right)$ ghost suspension in a total volume of $100 \mu \mathrm{l}$ incubating buffer. After a 3-h incubation at $37^{\circ} \mathrm{C}$, samples were cooled on ice and centrifuged at $15000 \times g$ for $10 \mathrm{~min}$. Supernatants were discarded and pelleted ghosts were suspended in $400 \mu \mathrm{l}$ of chloroform/methanol solution $(2: 1, \mathrm{v} / \mathrm{v})$ to extract the lipid. To identify the individual phospholipid species, $45 \mu \mathrm{l}$ of lipid extract was subjected to TLC on silica plates and separated using freshly prepared solvent system of chloroform/acetone/methanol/acetic acid/water $(50: 20: 10: 10: 5$, by vol.). After drying, the plates were analysed by fluorography. The lipids were visualized by exposure to iodine vapor.

To test the transfer of palmitate from free palCoA and from pal-CoA complexed with rhACBP to rhMPP-1 or endogenous membrane-bound protein acceptors, $3.5 \mu$ of packed native or heat-inactivated ghosts (see above) and $10 \mu \mathrm{M}$ holo-rhACBP (prepared as described above) or free $\left[{ }^{14} \mathrm{C}\right]$ pal-CoA $(2.5 \mu \mathrm{M})$ was added to $15 \mu \mathrm{g}$ of recombinant hMPP-1 in a total volume of $100 \mu$ l of incubating buffer. After a 3-h incubation at $37^{\circ} \mathrm{C}$, samples were cooled down on ice and then suspended in $1 \mathrm{ml}$ of chloroform/methanol solution $(1: 1, \mathrm{v} / \mathrm{v})$. The precipitated proteins were pelleted for $15 \mathrm{~min}$ at $15000 \times \mathrm{g}$, washed with $100 \mu \mathrm{l}$ of pure methanol, dried at $37^{\circ} \mathrm{C}$ for $15 \mathrm{~min}$, and finally dissolved in $25 \mu \mathrm{l}$ of SDS/PAGE sample buffer. 


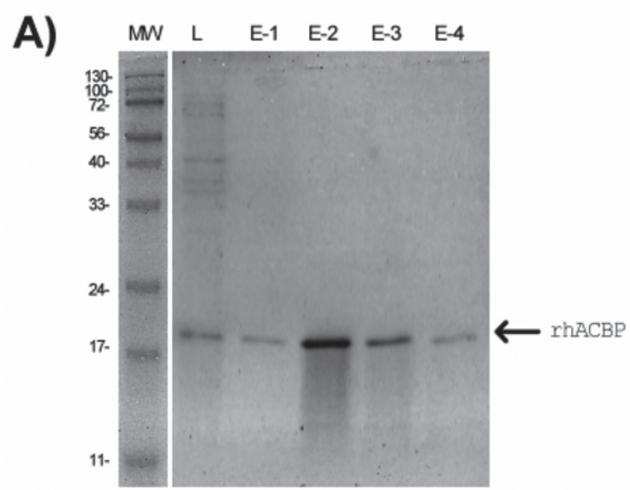

B)

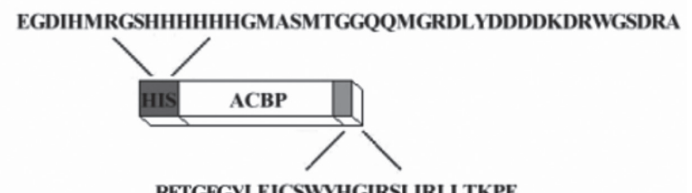

Figure 1. Recombinant acyl-Coenzyme A binding protein (ACBP) was efficiently expressed in $E$. coli

(A) Coomassie stained $14 \%$ SDS/PAGE gel shows purification of rhACBP on TALON resin. $L, E$. coli cell lysate; $E$, imidazole elution fractions (1-4); MW, molecular mass marker, KDa. (B) Diagram of organisation of fusion construct (His) ${ }_{6}$-ACBP. The tag amino-acid sequences are shown.

A)

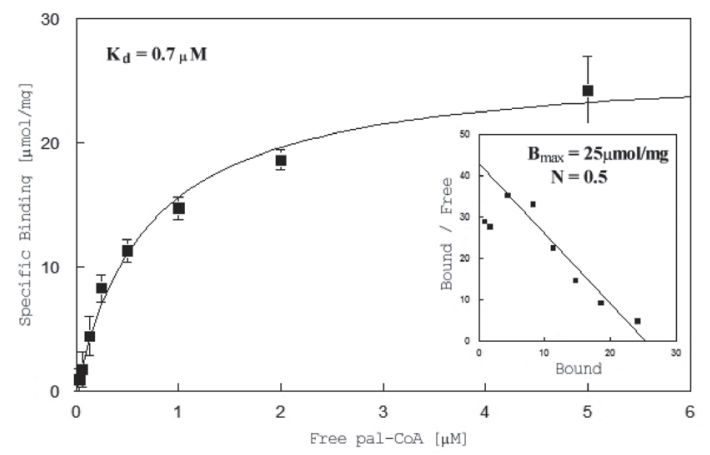

B)

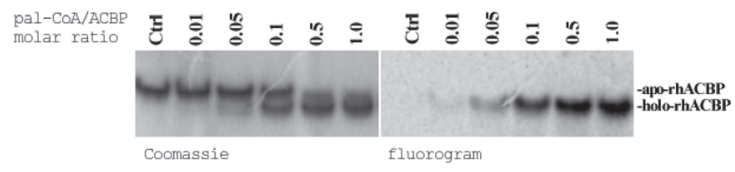

Figure 2. Recombinant hACBP binds pal-CoA with high affinity Binding assay was performed with $1 \mu \mathrm{M}$ recombinant hACBP and ${ }^{14} \mathrm{C}$-labelled pal-CoA at increasing concentrations $(0.03-5.0 \mu \mathrm{M})$. Unbound ligand was removed with TALON resin as described in Materials and Methods. (A) ACBP - pal-CoA binding kinetics. Error bars represent standard deviation of three independent experiments. Amount of pal-CoA bound vs. free pal-CoA is plotted as a Scatchard plot (inset) $K_{d}$, equilibrium dissociation constant; $\mathrm{N}$, number of binding sites ( $\left.\mathrm{N}=\mathrm{B}_{\max } /[\mathrm{rhACBP}]\right)$. (B) Coomassie blue-stained gel and its fluorogram show the binding of $\left[{ }^{14} \mathrm{C}\right]$ palCoA by rhACBP $(10 \mu \mathrm{M})$ in different molar ratios separated by native electrophoresis. The binding of palmitoyl-CoA is identified by band shift.
After heating at $95^{\circ} \mathrm{C}$ for $5 \mathrm{~min}$, the samples were analysed by SDS/PAGE (10\% gel) and autoradiography for 28 days at $-80^{\circ} \mathrm{C}$.

\section{RESULTS}

\section{Cloning, expression and purification of rhACBP}

cDNA sequencing confirmed the expected nucleotide sequence of human ACBP cDNA cloned in pRSET A. Its in silico translation into an amino-acid sequence is shown in Fig. 1B. The (His) ${ }_{6}$-ACBP fusion protein included the full-length native human ACBP amino-acid sequence (104 residues) and two additional sequences, an $\mathrm{N}$-terminal one of 44 amino-acids containing the His-tag and a 28-amino-acid fragment at the C-terminus.

The ACBP cDNA subcloned in the pRSET A/ rhACBP plasmid was highly expressed in E. coli BL21 under IP'TG induction after $2 \mathrm{~h}$. The Coomassie bluestained SDS-polyacrylamide gel shows the rhACBP protein before (Fig. 1A, lane L) and after (Fig. 1A, lanes E-1 to E-4) purification on the TALON resin. rhACBP with an apparent molecular mass of $21 \mathrm{kDa}$ was eluted in 1-ml fractions. The highest protein concentration was observed in the second fraction (E-2).

\section{Functional activity of rhACBP}

Binding of acyl-Coenzyme A. To determine if rhACBP expressed in bacteria was functionally active, its ability to bind palmitoyl-CoA was examined. The assay with radioactively labelled pal-CoA showed that it effectively bound pal-CoA and the equilibrium for this association was reached at the ratio of $1: 2$ (ligand/protein) with the equilibrium dissociation constant $\left(K_{\mathrm{d}}\right)$ of $7 \times 10^{-7} \mathrm{M}$ (Fig. 2A). Electrophoretic separation of rhACBP labelled with $\left.{ }^{14} \mathrm{C}\right]$ pal-CoA led to the appearance of an additional radiolabelled band in the gel that was also identified by Coomassie blue staining and was not visible in the control sample incubated without $\left[{ }^{14} \mathrm{C}\right] \mathrm{pal}-\mathrm{CoA}$. In the electric field the complex of rhACBP and pal-CoA runs distinctly faster than apo-protein (Fig. 2B). The radioactivity related to the ACBP is lost when the complex is treated with SDS.



Figure 3. Ligand-free rhACBP is monomeric form, whereas in complex with pal-CoA rhACBP forms a dimer

SDS/PAGE of rhACBP in its apo- and holo- form, in the presence or absence of the cross-linker. Positions of molecular mass standards $(\mathrm{kDa})$ are indicated on the left. Lanes: 1, holo-rhACBP incubated without DSS; 2, apo-rhACBP incubated in the presence of $25 \mathrm{mM}$ DSS; 3, holo-rhACBP incubated with $25 \mathrm{mM}$ DSS. Twenty microgram of protein was loaded per lane on $14 \%$ gel. 


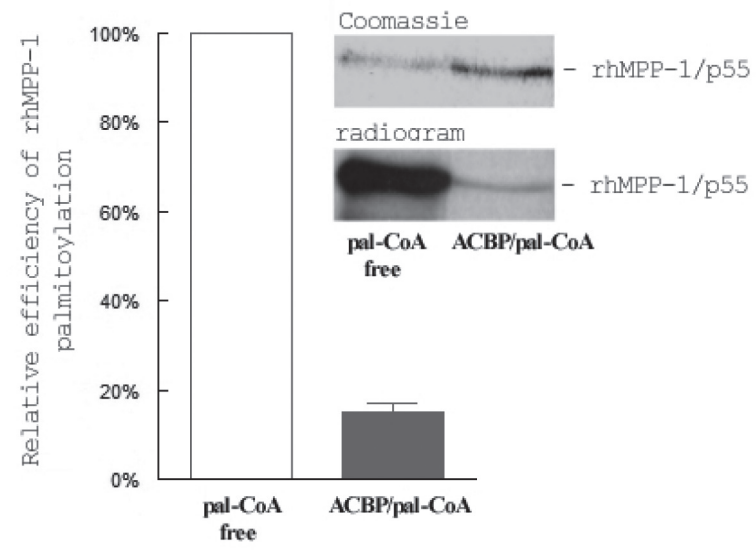

Figure 4. Binding of pal-CoA to rhACBP prevents spontaneous protein palmitoylation

Bar graph and gel (Coomassie stained - upper panel and its autoradiogram - bottom panel) show relative efficiency of rhMPP-1/p55 palmitoylation upon incubation with free $\left[{ }^{14} \mathrm{C}\right]$ palCoA (empty bar, $100 \%$ ) or purified rhACBP/[14 $\mathrm{C}]$ pal-CoA complex (filled bar, $15 \pm 2 \%$ ) in the absence of an enzyme source. Error bar represents standard deviation for three different experiments.

rhACBP oligomerisation. Changes of the apparent molecular mass of rhACBP of rhACBP were determined by SDS/PAGE using a 14\% gel. Relative to the molecular mass standards, rhACBP had an apparent molecular mass of approx. $20 \mathrm{kDa}$. SDS/PAGE analysis of rhACBP incubated with a cross-linker followed binding of pal-CoA by rhACBP indicated one major higher molecular mass band (approx. $40 \mathrm{kDa}$ ) compared with the protein incubated without the ligand (Fig. 3). These data clearly indicate that dimerization of rhACBP upon ligand binding could be detected by the addition of DSS and SDS/PAGE.

The effect of rhACBP on spontaneous protein palmitoylation. The effect of rhACBP on non-enzymatic/spontaneous palmitoylation of proteins was evaluated. In the presence of free pal-CoA rhMPP-1-p55 was highly palmitoylated in a dose- and time-dependent manner. When the purified rhACBP-pal-CoA complex was used as the source of palmitate, the efficiency of protein palmitoylation decreased, reaching approx. $15 \%$ of the control value (Fig. 4).

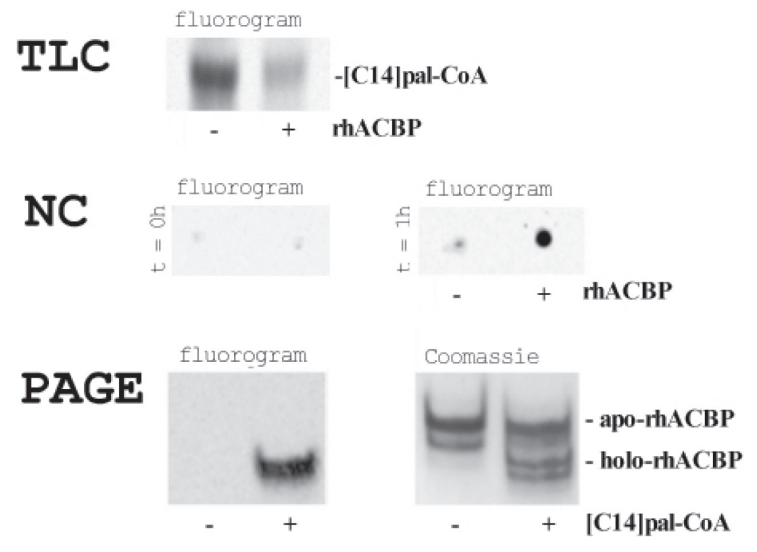

Figure 5. Recombinant hACBP desorbs membrane-bound palCoA with high efficiency forming rhACBP/pal-CoA complex

TLC: Fluorogram of TLC plate shows membrane-bound $\left[{ }^{14} \mathrm{C}\right]$ palCoA extracted from ghosts and separated after one-hour incubation in the presence $(+)$ or absence $(-)$ of rhACBP. NC: Fluorograms of nitrocellulose sheet show spots of reaction mixtures collected after pelleting of ghosts first equilibrated with $\left[{ }^{14} \mathrm{C}\right]$ pal-CoA and than incubated in the presence $(+)$ or absence $(-)$ of rhACBP. Left panel - control supernatants before incubation, right panel - supernatants after one-hour incubation at $37^{\circ} \mathrm{C}$. PAGE: Fluorogram (left) of native, Coomassie-stained gel (right) showing apoand holo-rhACBP in supernatants collected after incubation of rhACBP with membranes which were $(+)$ or were not $(-)$ equilibrated with $\left[{ }^{14} \mathrm{C}\right] \mathrm{pal}-\mathrm{CoA}$.

The effect of rhACBP on membrane-bound acylCoenzyme A. The ability of rhACBP to pull out palCoA associated with cellular membranes was tested. Palmitoyl-CoA easily penetrated into the erythrocyte membrane binding them with high affinity. During an hour incubation in the presence of rhACBP, the level of total ghost pal-CoAs was reduced by $67 \%$. As was observed in a native gel stained with Coomassie blue and confirmed by autoradiography (Fig. 5), rhACBP extracted the membrane-bound $\left[{ }^{14} \mathrm{C}\right] \mathrm{pal}-\mathrm{CoA}$, resulting in the formation of an rhACBP $/\left[{ }^{14} \mathrm{C}\right] \mathrm{pal}-\mathrm{CoA}$ complex.

The effect of rhACBP on enzymatic protein palmitoylation. The question of the role of rhACBP as a potential supplier of acyl-residues for enzymatic protein palmitoylation was addressed. Freshly prepared erythrocyte ghosts were used as a source of PAT (protein acyl-
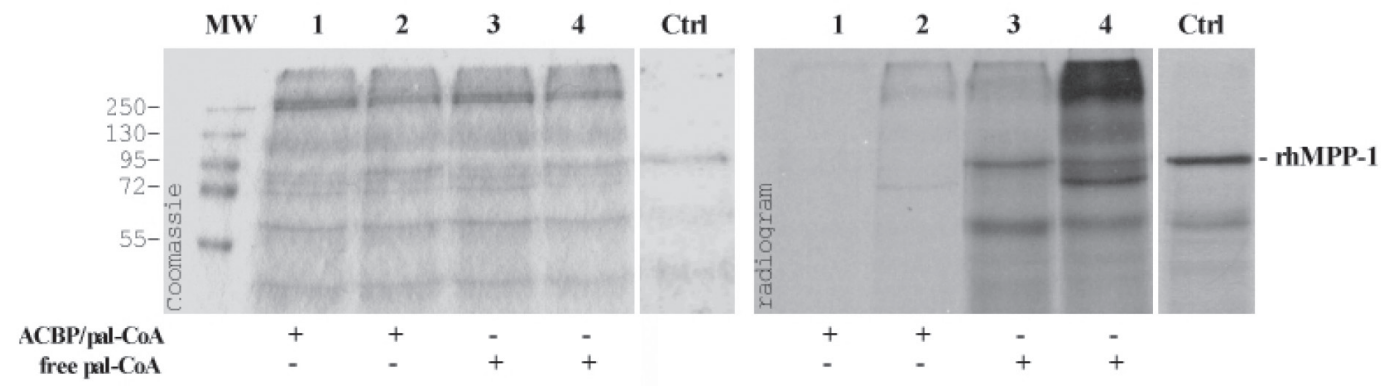

Figure 6. Pal-CoA bound to rhACBP is not used for enzymatic protein palmitoylation

Coomassie-stained gel (left) and its autoradiogram (right) show transfer of palmitate from pal-CoA (free form or bound to rhACBP) to rhMPP-1/p55 $(15 \mu \mathrm{g})$ in presence of native or heat-inactivated human erythrocyte membranes. Lane 1, rhMPP-1 incubated with purified rhACBP/pal-CoA complex in the presence of native ghosts; lane 2, rhMPP-1 incubated with purified rhACBP/pal-CoA complex in the presence of heat-inactivated ghosts; lane 3, rhMPP-1 incubated with free pal-CoA in the presence of native ghosts; lane 4, rhMPP-1 incubated with free pal-CoA in the presence of heat-inactivated ghosts. Ctrl, control, rhMPP-1 incubated with free pal-CoA without ghosts; MW, molecular mass marker kDa. 


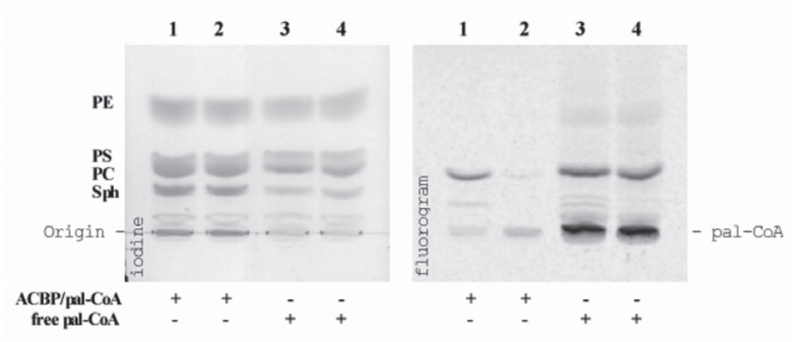

Figure 7. Pal-CoA bound to rhACBP is utilized for enzymatic membrane phospholipid (trans)palmitoylation

Erythrocyte membrane phospholipids were separated by TLC. Sph, sphingomyelin; PC, phosphatidylcholine; PS, phosphatidylserine; $\mathrm{PE}$, phosphatidylethanolamine. Lipid extracts $(45 \mu \mathrm{l})$ of erythrocyte membranes were applied on silica plates and resolved. lodinestained plate (left) and its fluorogram (right) show phospholipid bands of native ghosts (lane 1) and heat-inactivated ghosts (lane 2) after incubation in presence of purified $A C B P /\left[{ }^{14} \mathrm{C}\right]$ pal-CoA complex. Lanes 3 and 4, phospholipids derived from native and heat-inactivated ghosts, respectively, after incubation with free $\left[{ }^{14} \mathrm{C}\right]$ pal-CoA. In lanes 1 and 2 only faint bands of $\left[{ }^{14} \mathrm{C}\right]$ pal-CoA are visible, while in lanes 3 and 4 they are dominant.

transferase). Recombinant hMPP-1/p55 was used as an exogenous palmitate acceptor. Incubating free pal-CoA with rhMPP-1/p55 in the presence of native ghosts resulted in the covalent attachment of palmitate to the target protein. However, when free pal-CoA was substituted with the rhACBP/pal-CoA complex in the incubation mixture, no protein palmitoylation was observed. When the reaction was carried out in the presence of heat-inactivated ghosts, some integral membrane proteins besides rhMPP-1/p55 were palmitoylated efficiently, but using the complex instead of free pal-CoA significantly quenched this effect (Fig. 6).

The effect of rhACBP on membrane phospholipid palmitoylation. The functional activity of rhACBP as a supplier of palmitate for membrane phospholipid palmitoylation was tested. In the absence of rhACBP, adding free pal-CoA to native or heat-inactivated erythrocyte membranes led to the incorporation of palmitate into the ghosts' phosphatidylethanolamine (PE) and, even more efficiently, into phosphatidylcholine (PC). When the purified rhACBP/pal-CoA complex was added instead of free pal-CoA, only PC palmitoylation was observed. Moreover, radioactive-labelled phosphatidylcholine only formed in the presence of the complex when native ghosts were used. In the presence of heatinactivated ghosts, adding the rhACBP/pal-CoA complex resulted in a very low level of PC palmitoylation (Fig. 7).

\section{DISCUSSION}

Long-chain fatty acid Coenzyme A thioesters are known to play an essential role in all organisms. They are an important pool of fatty donors for a large number of various cellular processes, including phospholipid and protein acylation. The mechanism of acylation itself indicates that the availability of acyl-CoAs is important for the regulation of this process. Within the cell, longchain acyl-CoAs bind non-covalently and reversibly with a relatively high affinity to acyl-CoA binding proteins (ACBPs). As is widely accepted, the formation of the complex significantly reduces the intracellular concentration of free long-chain acyl-CoAs and simultaneously protects them from uncontrolled hydrolysis (Færgeman et al., 2007). While the physiological role of ACBPs as an intracellular guard of the long-chain acyl-CoA pool has been well established, the phenomenon of donation of acyl-CoAs to enzymes utilizing them is still unclear, in particular the acyl transfer onto proteins.

ACBP was originally identified as a mammalian diazepam-binding inhibitor: a neuropeptide that could inhibit diazepam binding to the $\gamma$-aminobutyric acid (GABA) receptor (Guidotti et al., 1983). In humans, ACBP is one of the six members of the acyl-CoAbinding domain-containing (ACBD) family. In 1995, Fryst and co-workers showed that mature human red blood cells contained a $10-\mathrm{kDa}$ protein that binds arachidonyl-CoA and cross-reacts with an antibody directed against ACBP isolated from the human liver. Here, for the first time, a fragment identical to the full-length cDNA of the Homo sapiens diazepam-binding inhibitor (DBI; GABA receptor modulator, or acyl-Coenzyme-Abinding protein), transcript variant 1 (NCBI Reference Sequence: NM_020548.5) was identified by RT-PCR in human reticulocytes derived from a healthy donor. The PCR product was subcloned into pRSET A vector and successfully expressed and purified to a high yield from E. coli.

Using a radioactivity-based binding assay, we found that erythroid rhACBP was able to bind palmitoyl-CoA. However, the $K_{\mathrm{d}}=7 \times 10^{-7} \mathrm{M}$ calculated for the complex of this protein with palmitoyl-CoA is significantly higher than previously reported values, which were in the $0.45 \times 10^{-13}$ to $0.6 \times 10^{-8} \mathrm{M}$ range (Leventis et al., 1987 ; Rasmussen et al., 1994). It is possible that the real affinity of rhACBP for pal-CoA is higher than that calculated, and the difference results from the different method of the "bound" value estimation or from the fact that the bacterially expressed protein is not properly folded. However, this possibility is unlikely as the recombinant protein is functionally active.

In contrast to the previously observed 1:1 stoichiometry of the binding of acyl-CoA to ACBP (Knudsen et al., 1989; Gossett et al., 1998), we found that one ligand molecule binds two protein molecules. This is acceptable if we consider the dimeric mode of binding of acyl-CoA on ACBP presented by Taskinen et al. (2007). In this way, the acyl-CoA molecule is bound across the two protein molecules. The adenosine 3'-monophosphate moiety is bound in the binding pocket of one ACBP molecule, and the acyl chain is bound in the pocket of the other ACBP molecule. The use of the DSS crosslinker in our study confirmed that rhACBP interacting with ligand shifts from the monomeric to the dimeric state. Recently, it has been found that ACBP of Moniliophthora perniciosa favoured a dimeric form when it was liganded to longer-chain acyl-CoA esters, such as palmitoyl-, stearoyl- or arachidoyl-CoA (Monzani et al., 2010).

Acyl-CoA binding proteins from the rat and bovine livers were found to strongly inhibit spontaneous/nonenzymatic S-acylation of proteins by long-chain acylCoAs (Leventis et al., 1987; Dunphy et al., 2000). Our results provide evidence that in vitro palmitoylation of MPP-1/p55 with free pal-CoA occurs in the absence of an enzyme source. However, supplying the pal-CoA in a complex with rhACBP abrogated this reaction. The recombinant ACBP was found to protect MPP-1/p55 against non-enzymatic palmitoylation. This data is in agreement with those in previous studies and shows that acyl-CoA bound to ACBP is not available for spontaneous S-acyl-transfer. 
Long-chain acyl-CoA esters have a high affinity for biological membranes and can associate with them by insertion of the fatty acyl chain into the bilayer core (Boylan \& Hamilton, 1992; Rasmussen et al., 1994; Simonsen et al., 2003). The partition constant $\left(K_{\mathrm{d}}\right)$ for palmitoylCoA into phospholipid vesicles was calculated to be in the range from $1.5 \times 10^{5} \mathrm{M}^{-1}$ to $5 \times 10^{5} \mathrm{M}^{-1}$ (Knudsen et al., 2000). Studies of the interactions of ACBP with membranes showed that recombinant bovine ACBP could desorb a substantial fraction of palmitoyl-CoA bound to phosphatidylcholine membranes immobilized on nitrocellulose (Rasmussen et al., 1994). In our study, rhACBP desorbed pal-CoA incorporated in erythrocyte membranes to form an rhACBP/pal-CoA complex. These results are thus consistent with those from earlier research and suggest that ACBP may be involved in maintaining the intracellular pal-CoA pool.

It was found that ACBP provides acyl-CoA for mitochondrial $\beta$-oxidation and for microsomal phosphatidic acid biosynthesis (Knudsen et al., 1994; Jolly et al., 2000). It was noticed that carnitine palmitoyltransferase I (CPT I) directly interacts with the acyl-CoA/ACBP complex (Abo-Hashema et al., 2001). Our results clearly demonstrate that rhACBP acts as a supplier of palmitoyl-CoA for phospholipid acyltransferase(s) with preferences to generate palmitoyl-phosphatidylcholine (PC). The efficiency of palmitate transfer from the complex to PC in heat-inactivated membranes was low, so the participation of enzyme(s) in this reaction is evident. Erythrocytes cannot synthesize phospholipids de novo. In these cells, the turnover of phospholipid fatty acids is limited to the deacylation and reacylation of existing endogenous phospholipids (Dise et al., 1980). Rapid turnover of the acyl moiety was originally described by Lands as the remodelling pathway (Lands' cycle), and was attributed to the coordinated actions of phospholipases (PLAs) and lysophospholipid acyltransferases (LPLTs). However, although this process has been known for 50 years, detailed information on its mechanism is still lacking (Soupene et al., 2008; Shindou \& Shimi, 2009). It is interesting that the presence of free pal-CoA led to an equal incorporation of palmitate into the phospholipids of both native and heat-inactivated membranes, indicating that the reaction might have a non-enzymatic character. This fact seems to underline the role of the erythrocyte ACBP in the control of the Lands' cycle, and thus in the maintenance of the membrane's lateral and transbilayer asymmetry and diversity, which are also important for its fluidity and curvature.

Since ACBP can donate palmitate to the enzyme(s) catalyzing phospholipid palmitoylation, it might be expected to play a similar role in respect to protein palmitoyltransferase(s). Protein palmitoylation refers to the addition of palmitate to a cysteine residue, and in vivo it is catalysed by a family of enzymes that share a conserved DHHC (Asp-His-His-Cys) cysteine-rich domain. Unlike other forms of protein lipidation, such as prenylation and myristoylation, palmitoylation is reversible and can therefore play a regulatory role in the cell (Baekkeskov \& Kanaani, 2009; Iwanaga et al., 2009). In red blood cells protein palmitoylation seems to be a common phenomenon and corresponds to the organising role in associations of cytoskeletal proteins with the membrane (Schmidt et al., 1995). Dunphy et al. (2000), characterizing the effect of ACBP on protein thioacylation, found that the enzymatic palmitoylation of a myristoylated peptide or $G$-protein $\alpha$-subunits was not affected in the presence of ACBP. In this study, we used complexed
ACBP purified on TALON resin to make sure that the incubation mixture was free of unbound pal-CoA, which might give incorrect results. Our data clearly indicates that when pal-CoA is in a complex with rhACBP, it is not available as a substrate for enzymatic protein palmitoylation. We have to consider the possibility that the presence of fusion fragments in the recombinant ACBP result in subtle conformational changes which, while not affecting the ligand binding or functional connections with enzyme(s) involved in phospatidylcholine acyl chain remodelling, might affect the direct interactions of the protein with membrane palmitoyltransferase(s). The fact that the complex is available for PC transacylating enzyme(s) makes this possibility rather unikely.

In conclusion, we have clearly established that the mRNA fragment identical to the diazepam-binding inhibitor mRNA, the most common isoform of the human acyl-CoA-binding domain-containing (ACBD) family, is expressed in human reticulocytes. The ability of recombinant ACBP to desorb membrane-anchored pal-CoA and form a complex with it suggests that in erythroid cells ACBP takes part in the regulation of intracellular free pal-CoA concentration. Another important feature of this protein seems to be that it specifically donates pal-CoA to the acyltransferas(s) involved in membrane PC palmitoylation. Although ACBP does not supply palmitate to PAT(s), it may effectively protect membrane proteins against spontaneous palmitoylation.

\section{Acknowledgement}

This work was supported by grant N N301 161435 from the Ministry of Science and Education to A.F.S.

\section{RRFERENCES}

Abo-Hashema KAH, Cake MH, Lukas MA, Knudsen J (2001) The interaction of acyl-CoA with acyl-CoA binding protein and carnitine palmitoyltransferase I. Int J Biochem Cell Biol 33: 807-815.

Baekkeskov N, Kanaani J (2009) Palmitoylation cycles and regulation of protein function. Mol Membr Biol 26: 42-54.

Boylan JG, Hamilton JA (1992) Interactions of acyl-Coenzyme A with phosphatidylcholine bilayers and serum albumin? Biochemistry 31: $557-567$.

Dise CA, Goodman DBP, Rasmussen H (1980) Definition of the pathway for membrane phospholipid fatty acid turnover in human erythrocytes. J Lipid Res 21: 292-300.

Dodge JT, Mitchell C, Hanahan DJ (1963) The preparation and chemical characteristics of hemoglobin-free ghosts of erythrocytes. Arch Biochem 100: 119-130.

Dunphy JT, Schroeder H, Leventis R, Greentree WK, Knudsen JK, Silvius JR, Linder ME (2000) Differential effects of acyl-CoA binding protein on enzymatic and non-enzymatic thioacylation of protein and peptide substrates. Biochim Biophys Acta 1485: 185-198.

Færgeman NJ, Knudsen J (1997) Role of long-chain fatty acyl-CoA esters in the regulation of metabolism and in cell signaling. Biochem $J$ 323: $1-12$

Færgeman NJ, Wadum M, Feddersen S, Burton M, Kragelund BB, Knudsen J (2007) Acyl-CoA binding proteins; structural and functional conservation over 2000 MYA. Mol Cell Biochem 299: 55-65.

Fyrst H, Knudsen J, Schott MA, Lubin BH, Kuypers FA (1995) Detection of acyl-CoA-binding protein in human red blood cells and investigation of its role in membrane phospholipid renewal. Biochem J 306: 793-799.

Gossett RE, Frolov AA, Roths JB, Behnke WD, Kier AB, Schroeder F (1996) Acyl-CoA binding proteins: multiplicity and function. Lipids 31: 895-918.

Gossett RE, Edmondson RD, Jolly CA, Cho TH, Russell DH, Knudsen J, Kier AB, Schroeder F (1998) Structure and function of nor$\mathrm{mal}$ and transformed murine Acyl-CoA binding proteins. Arch Biochem Biophys 350: 201-213.

Guidotti A, Forchetti CM, Corda MG, Konkel D, Bennett DD, Costa E (1983) Isolation, characterization, and purification to homogeneity of an endogenous polypeptide with agonistic action on benzodi- 
azepine receptors (endogenous benzodiazepine ligand/GABA receptor/anxiety/partial peptide sequence). Neurobiology 80: 3531-3535.

Hu L, Deeney JT, Nolan CJ, Peyot ML, Ao A, Richard AM, Luc E, Faergeman NJ, Knudsen J, Guo W, Sorhede-Winzell M, Prentki M, Corkey BE (2005) Regulation of lipolytic activity by long-chain acylcoenzyme $\mathrm{A}$ in islets and adipocytes. Am J Physiol Endocrinol Metab 289: E1085-E1092.

Iwanaga T, Tsutsumi R, Noritake J, Fukata Y, Fukata M (2009) Dynamic protein palmitoylation in cellular signaling. Prog Lipid Res 48: $117-127$.

Jolly CA, Wilton DC, Schroeder F (2000) Microsomal fatty acyl-CoA transacylation and hydrolysis: fatty acyl-CoA species dependent modulation by liver fatty acyl-CoA binding proteins. Biochim Biophys Acta 1483: 185-197.

Knudsen J, Højrup P, Hansen HO, Hansen HF, Roepstroff P (1989) Acyl-CoA-binding protein in the rat. Purification, binding characteristics, tissue concentrations and amino acid sequence. Biochem $J$ 262: 513-519.

Knudsen J, Færgeman NJ, Skøtt H, Hummel R, Børsting C, Rose TM, Andersen JS, Højrup P, Roepstorfft P, Kristiansen K (1994) Yeast acyl-CoA-binding protein: acyl-CoA-binding affinity and effect on intracellular acyl-CoA pool size. Biochem J 302: 479-485.

Knudsen J, Neergaard TBF, Gaigg B, Jensen MV, Hansen JK (2000) Role of acyl-CoA binding protein in acyl-CoA metabolism and acylCoA-mediated cell signaling. I Nutr 130: 294S-298S.

Leventis R, Juel G, Knudsen JK, Silvius JR (1987) Acyl-CoA binding proteins inhibit the nonenzymic S-acylation of cysteinyl-containing peptide sequences by long-chain acyl-CoAs. Biochemistry 36: 55465553.

Linder ME, Deschenes RJ (2007) Palmitoylation: policing protein stability and traffic. Nature 8: 74-84.

Mitchell GA, Gauthier N, Lesimple A, Wang SP, Mamer O, Qureshi I (2008) Hereditary and acquired diseases of acyl-coenzyme A metabolism. Mol Genet Metab 94: 4-15.
Monzani PS, Pereira HM, Melo FA, Meirelles FV, Oliva G, Cascardo JCM (2010) A new topology of ACBP from Moniliophthora perniciosa. Biochim Biophys Acta 1804: 115-123.

Pfanner N, Glick BS, Arden SR, Rothman JE (1990) Fatty acylation promotes fusion of transport vesicles with golgi cisternae. J Cell Biol 110: $955-961$.

Rasmussen JT, Fiergeman NJ, Kristiansent K, Knudsen J (1994) AcylCoA-binding protein (ACBP) can mediate intermembrane acyl-CoA transport and donate acyl-CoA for $\beta$-oxidation and glycerolipid synthesis. Biochem J 299: 165-170.

Rosendal J, Ertbjerg P, Knudsen J (1993) Characterization of ligand binding to acyl-CoA-binding protein. Biochem J 290: 321-326.

Schmidt MFG, McIlhinney RAJ, Burns GR (1995) Palmitoylation of endogenous and viral acceptor proteins by fatty acyltransferase (PAT) present in erythrocyte ghosts and in placental membranes. Biochim Biophys Acta 1257: 205-213.

Shindou H, Shimi T (2009) Acyl-CoA:lysophospholipid acyltransferases. I Biol Chem 284: 1-5.

Shrago E (2000) Long-chain acyl-CoA as a multi-effector ligand in cellular metabolism. J Nutr 130: 290S-293S.

Simonsen AC, Jensen UB, Færgeman NJ, Knudsen J, Mouritsen OG (2003) Acyl-coenzyme A organizes laterally in membranes and is recognized specifically by acyl-coenzyme A binding protein. FEBS Lett 552: 253-258.

Soupene E, Fyrst H, Kuypers FA (2008) Mammalian acyl CoA:lysophosphatidylcholine acyltransferase enzymes. Proc Natl Acad Sci USA 105: 88-93.

Taskinen JP, van Aalten DM, Knudsen J, Wierenga RK (2007) High resolution crystal structures of unliganded and liganded human liver ACBP reveal a new mode of binding for the acyl-CoA ligand. Proteins: Structure, Function and Bioinformatics 66: 229-238. 